\title{
Exploration of University Faculty Perceptions and Experiences of Service-Learning as Engaged Scholarship of Teaching and Learning
}

\author{
Dr. Irene Arellano \\ Texas Tech University \\ Dr. Stephanie J. Jones \\ Texas Tech University
}

\begin{abstract}
The purpose of this qualitative instrumental case study was to explore how faculty at a private research university utilize the service-learning pedagogy to advance their scholarship of teaching and learning. Of specific interest was what influences them to utilize the service-learning pedagogy in their scholarship of teaching and learning, and how they perceive that utilizing the service-learning pedagogy affects student learning. Boyer's work on the scholarship of teaching and learning framed the study. The findings of this study are that the experiential components of the service-learning pedagogy are effective in connecting students to real-world problems. As part of the curriculum it engages students in deeper learning and its use changes students' perspectives about the importance of community involvement, establishing a community consciousness to those students involved. The study supports that the service-learning pedagogy is important to higher education faculty and has led to supporting their scholarship of teaching and learning.
\end{abstract}

Keywords: service-learning, university faculty, scholarship of teaching and learning, pedagogy, engaged scholarship

In addition to helping students achieve their academic success, faculty in higher education also have their own professional goals (Bowdon, Billig, \& Holland, 2008). One way that faculty can enhance these roles is through the integration of their scholarship of teaching and learning through service-learning. The scholarship of teaching and learning (SoTL) is described by McKinney (2006) as involving the "systematic study of teaching and/or learning and the public sharing and review of such work through presentations, performance, or publications" (p. 39). Bringle and Hatcher (1995) define service-learning as “...a course-based service experience that allows the students to participate in an organized service activity in such a way as to gain further understanding of course content, a broader appreciation of the discipline, and enhanced sense of civic responsibility" (p. 112).

With its roots in the foundational work of John Dewey (1938), the service-learning pedagogy is based on experiences in which things are not known and are learned. Servicelearning provides opportunities for faculty to become more aware of student outcomes, advances students' interest in community engagement, as well as provides opportunities for faculty to collaborate with their colleagues across disciplines (Cooper, 2013). In addition, faculty who utilize the service-learning pedagogy in their courses provide students the opportunity to be engaged in the course and in the community - both which are shown to enhance student learning (Jacoby \& Associates, 1996; Redlawsk, Rice, \& Associates, 2009; 
Stelljes, 2008). It is also through the service-learning pedagogy that faculty can inform their teaching practice (Cooper, 2013) by including intentional reflection that is designed to enable students to learn (Dewey, 1933; Jacoby, 2003; Jacoby \& Associates, 1996).

When faculty's work and research on service-learning increases the understanding of teaching and learning in a discipline, then it has the potential to be viewed as scholarship within the context of the scholarship of teaching and learning (Bringle, Hatcher, \& Clayton, 2006; Clayton, Bringle, \& Hatcher, 2013). The extant research on service-learning is focused on its benefits for students, such as intellectual, ethical, and personal development (e.g., Astin \& Sax, 1998; Bok, 2006; Eyler \& Giles, 1999), and civic responsibility (e.g., Bok, 2006). There is also research on the benefits of service-learning for the community partners (e.g., Seifer \& Connors, 2007; Westover, 2012; Wilczenski \& Coomey, 2007). According to Cooper (2013), additional research is needed that focuses on the perceptions, attitudes, experiences, and beliefs of faculty who have embraced and value service-learning as a pedagogy, as well as why they choose to use it as a pedagogical strategy (Strait \& Lima, 2009).

Strait and Lima (2009) claim that the service-learning field can benefit from more indepth analyses of both the merits and shortcomings of service-learning, in particular faculty perceptions and experiences of utilizing it in their teaching and learning. Higher education institutions can benefit from having a better understanding of the different components of service-learning and how they relate to faculty's scholarship of teaching and learning. In an effort to enhance student learning, higher education institutions face the challenges of providing alternative teaching methods in the classroom (Ward, 2003). As noted by Li, Greenberg, and Nicholls (2007), college students expect more stimulating learnings experiences. The inclusion of a service-learning component in the course curriculum has not only been shown to enhance student learning, but it has also been shown to enhance the scholarship of teaching and learning for faculty (Boyer, 1990; Ward, 2003).

Service-learning in higher education would not exist without faculty acceptance of it as a valid educational pedagogy (Langseth \& Plater, 2004; Strait \& Lima, 2009). Faculty members participate in service-learning because of their personal commitment to the pedagogy (Birge, 2005; Schwendener-Holt, 2005) and to enhance student learning (Bowen, 2010). Faculty's passion and persistence in the integration of service-learning into their courses have helped raise its visibility in higher education (Strait \& Lima, 2009).

Birge (2005) posits that "without addressing the aesthetical underpinnings to our practice of service-learning, faculty may be building the structure of service-learning that lacks a deeper connection to the fundamental reasons for the work, and ultimately disables the foundation and sustainability of service-learning" (p. 203). According to Birge (2005) and Strait and Lima (2009), the service-learning pedagogy supports teaching that has a specific focus and that goes beyond simply knowledge sharing, helping to establish a thorough "understanding of the intersections between knowledge, experience, and self-understanding" (Butin, 2010, p. 198). The thought behind the purpose of teaching and learning relies on the idea that the power of the personal experience will compel the student to learn more profoundly and be able to apply knowledge more broadly (Birge, 2005). The concept then becomes that the student and faculty member share a mutual philosophy of engagement, both personal and professional within the course, learning, community, and oneself (Birge, 2005; Strait \& Lima, 2009).

In Billig, Root, and Jesse's (2005) study, the researchers found that using servicelearning to teach academic content and course objectives was a strong predictor of academic outcomes. As a pedagogical tool, service-learning also engages the students in the community 
and supports the institution as a socially-engaged campus (Bringle, Phillips, \& Hudson, 2004; Langseth \& Plater, 2004; Stelljes, 2008), helping to prepare students for their professional and citizen roles (Zlotkowski, 1998). Teaching with the service-learning pedagogy means faculty must pay more attention to how they teach and how students learn (Ehrlich, 2000). According to Connors, Kirk, and Seifer (2000), service-learning has caused multiple changes to occur in higher education, including the way faculty teach, how academic programs interact with communities, and has enabled organizations and their members to have a role in educating students.

Faculty "efforts are the first steps to truly integrating and reconceptualizing research, teaching, and service as discovery, learning, and engagement" (Welch \& Billig, 2004, p. 236). Not only is teaching imperative in faculty's careers, but at many four-year colleges and universities, research can play an equally or higher role in the process of tenure (Jacoby \& Mutascio, 2010; Keshen, Holland, \& Moely, 2010). The progression from engaging with service-learning as a professor to engaging with it as a scholar is realized through opportunities to conduct research (Jacoby \& Mutascio, 2010). Faculty members can utilize their servicelearning experiences in their research by connecting the pedagogy to their roles as scholars (Jacoby \& Mutascio).

Bowdon et al. (2008) posited that one of the challenges in service-learning research is how to show the importance of the pedagogy within the scholarship of teaching and learning. To advance the practice of service-learning, it is important that faculty "see that their scholarly work can and should continue to contribute to the body of knowledge within their own fields while simultaneously contributing to community improvement and students' civic engagement" (Welch \& Billig, 2004, p. 231). Research on service-learning has made substantial progress in the terms of rigor of studies (e.g., Bowdon et al., 2008; Vogel, Siefer, \& Gelmon, 2010) but as Keshan, Holland, and Moely (2010) noted, there is still much research needed that remains to be known and understood about service-learning in terms of knowledge and practice.

The exploration of how faculty perceive their experiences with the service-learning pedagogy, and how they perceive it contributes to their scholarship of teaching and learning is significant for higher education institutions. The purpose of the study was to explore how faculty at a research university utilize the service-learning pedagogy to advance their scholarship of teaching and learning. The study was guided by two research questions: (1) What influences university faculty to utilize the service-learning pedagogy in their scholarship of teaching and learning? (2) How do university faculty perceive that utilizing the service-learning pedagogy affects student learning?

\section{Scholarship of Teaching and Learning (SoTL)}

In order to discuss service-learning in the context of the scholarship of teaching and learning (SoTL), it is important to provide a brief discussion of Boyer's (1990) work. Boyer has become the foundation of higher education's efforts to redesign reward structures around expanded definitions of scholarship, in particular for faculty (Ward, 2003), which places emphasis on the aspects of teaching and learning.

Boyer (1990) argued that institutions of higher education should connect and integrate scholarship and service, and should be open to his vision of scholarship. Hence, faculty members utilizing the service-learning pedagogy can implement it in their scholarly endeavors (Bowen, 2010). According to Butin (2010), in order for service-learning to be sustainable and 
impactful, there must be an emergence of practice and research relative to the service-learning pedagogy. As a result of Butin's research, service-learning is not only recognized as a pedagogy but also as having a role in the scholarship of teaching and learning (Welch \& Billig, 2004).

Boyer (1990) identified a challenge to higher education is how to define faculty work in ways that enrich the quality of campus life. In Bowen's (2010) study, which was a qualitative content analysis of selected peer-reviewed journal articles reporting scholarship of teaching and learning studies of service-learning practice, faculty revealed the most common concept in their scholarship of teaching and learning projects was reflection. The faculty used reflections to inform their practice and to document their work.

"Critical reflection, discourse, and reflective action" have existed "in the real world in complex institutional, interpersonal, and historical settings," significantly influencing the potential "for transformative learning" (Merizow, 2000. p. 24). In support of critical reflection, "faculty involved in SoTL work tend to ask 'instrumental' questions, addressing the effectiveness of new, scholarly teaching methods with regard to whether they lead to more or better learning than do traditional methods" (Bowen, 2010, p. 3). It is Boyer's (1990) work that has influenced the nature of faculty scholarship beyond the traditional methods (Cruz, Ellern, Ford, Moss, \& White, 2013).

Boyer (1996) perceives scholarship as discovery, integration, teaching, and application. These four concepts are considered the scholarship of engagement due to their ability to connect with the needs of the extended community (Ward, 2003). The scholarship of discovery is considered the original and traditional research that advances knowledge through publication and or authoring and editing books, as well as disseminating this knowledge through conference presentations (Cruz et al., 2013). The scholarship of discovery has "promoted the development of new knowledge through collaboration with community and students that addressed critical needs in society" (Welch \& Billig, 2004, p. 233). The scholarship of integration involves the synthesis of information across disciplines or across time, which extends the common practice of research (Cruz et al., 2013). The scholarship of teaching is the systematic study of teaching and learning practices (Glassick, 2000).

In order to distinguish between the scholarship of teaching and scholarly teaching, Shulman (2004) states here are three criteria of scholarship that should be met: (1) it must be made public; (2) it must be available for peer review and critique, according to accepted standards; and (3) it must be made available to and used by other scholars. These criteria differentiate teaching from the scholarship of teaching. In essence, the faculty's work has a role in the scholarship of engagement, and an impact on the scholarship of teaching and learning.

Boyer (1996) mentioned that the scholarship of application and the scholarship of engagement have become synonymous, with focus on "social, civic, and ethical problems" ( $p$. 11). In the current study, the scholarship of application is discussed in the context of the scholarship of engagement. The scholarship of engagement goes beyond the provision of service to those within or outside the college or university (Cruz et al., 2013); therefore, servicelearning goes beyond the scope of the university community (Keshen et al., 2010). The scholarship of engagement is important to service-learning because it allows faculty to move beyond traditional research to a more active scholarly agenda that is beyond the walls of the higher education institution (Casey, Davidson, Billig, \& Springer, 2006). 


\section{Engaged Scholarship}

One way to make service-learning a more central role to the academic career of faculty is through the scholarship of engagement (Ward, 2003). Boyer (1996) discussed the scholarship of engagement as redefining the scholarly work of faculty from a focus on application of one's academic expertise to that of community-engaged scholarship that involves reciprocal partnerships with the community, is interdisciplinary, and integrates faculty roles of teaching, research, and service (Boyer, 1996). By utilizing the scholarship of engagement, faculty can use "their work in addressing community needs as a means to connect and apply disciplinary expertise to needs in the community and to integrate the lessons learned into their research and teaching" (Ward, 2003, pp. 7-8).

Boyer (1996) challenged higher education institutions to engage with the communities that surround them. According to Ward (2003), when outreach and service activities are treated as scholarship, faculty resources are fully utilized. Glassick (2000) mentioned that "expanding the definition of scholarship not only allows rewards to traditional research scholars but enfranchises many fine faculty whose work is in the area of application or engagement" ( $\mathrm{p}$. 880). According to multiple authors, service-learning aligns with and is consistent with the mission of higher education to develop the scholarship of engagement through collaborative work (e.g., Boyer, 1996; Bringle, Hatcher, \& Games, 1997; Butin, 2010; Zlotkowski, 1998). Cruz et al. (2013) mention that "to be considered scholarship, there must an application of disciplinary expertise with results that can be shared with and/or evaluated by peers" (p. 8).

Boyer (1996) stated that "scholarship engagement also means creating a special climate in which academic and civic cultures communicate more continuously and more creatively with each other...enriching the quality of life for all of us" (p. 20). In addition, it supports working in collaboration across disciplines and between academic and community partners (Cress, Collier, Reitenauer, \& Associates, 2005; Cruz et al., 2013). Educators who relate their academic work with the engagement movement are more likely to draw from the service-learning pedagogy for generating knowledge and practices as its elements are applicable to assisting with social issues affecting a community (Strait \& Lima, 2009).

Supporters of service-learning have called on service-learning and community engagement scholars to conduct more research with community partners (Bowdon et al., 2008). Engagement with community partners allows higher education institutions and the community to exchange knowledge and resources in a context of collaboration and reciprocity for the betterment of both entities (Strait \& Lima, 2009). Faculty can benefit from their relationships with community partners by not only enhancing student learning but also by enhancing their studies and engaged research.

The scholarship of teaching and learning can be advanced when faculty or practitioners move beyond anecdotes and provide empirical evidence of teaching effectiveness in their reports, teaching evaluations, and publications (Bowen, 2010). Service-learning improves research by broadening academic thinking and creating results with greater impact and relevance (Fitzgerald et al., 2012). Scholars have been empowered by Boyer's $(1990,1996)$ concepts, and the role of engaged scholarship at colleges and universities is evolving nationwide and worldwide (Glassick, 2000). 


\section{Conceptual Framework of the Study}

The conceptual framework that framed this study is based on the concepts of Boyer's (1990) Scholarship Reconsidered: Priorities of the Professoriate, which provides a foundation for faculty in the context of service-learning and their research through the four levels of scholarship: (1) discovery; (2) teaching; (3) application; and (4) integration. Boyer suggests that faculty's knowledge, integrity, persistence, and creativity are important factors in influencing their views and thoughts on scholarship.

\section{Methodology}

This qualitative collective case study, conducted through the lens of the naturalistic paradigm, was used to explore faculty perceptions of the service-learning pedagogy in their scholarship of teaching and learning. Participants for this study were seven purposefully-selected faculty who were engaged in service-learning at the study institution. The inclusion criteria for participants were that they had at least three years and beyond experience with service-learning, and had an understanding of the service-learning pedagogy and research.

Data collection included semi-structured interviews, documents (e.g., syllabus; publications), field notes, and reflective journaling. Of the seven total interviews, five were conducted in-person at the participants' work setting and two were conducted by telephone. The interviews lasted between 45 and 75 minutes. All interviews were audio-recorded and were transcribed by the researchers.

Data analysis was conducted through the use of the constant comparison method (Erlandson, Harris, Skipper, \& Allen, 1993; Merriam, 2009) and open coding (Merriam, 2009) in order to discover categories and themes. Trustworthiness of the study, specifically its credibility, dependability, confirmability, and transferability, was ensured through appropriate qualitative measures including triangulation of the data; peer debriefing; an audit trail; rich, thick descriptions; and reflective journaling (Lincoln \& Guba, 1985).

The researchers held the following assumptions in this study. The first was that all of the participants answered the interview questions honestly. The second was that they had knowledge of how the service-learning pedagogy advances the scholarship of teaching and learning.

The limitations to this study are that due to geographic limitations and the researchers' ability to travel, the participants were selected from one private research university located in the North region of Texas. Although faculty members are frequently studied collectively with their peers, the findings and recommendations of this study are specifically contextualized to faculty members who have experience with the service-learning pedagogy. The transferability of the results of this study is up to the discretion of the reader.

\section{Study Institution and Participants}

The setting for this study was a private, four-year liberal arts research university located in the North region of Texas. According to the Carnegie Classification System (n.d.), the institution has 119 undergraduate majors, offers 53 master's programs, and 28 doctoral programs. Enrollments at the institution in 2015-2016 were over 10,000 students, with a majority of them being undergraduates and women $(59.8 \%)$. The study institution is committed to service 
learning, demonstrated by the establishment of a center to support faculty and students in their community involvement initiatives.

The participants in this study were seven service-learning faculty at the study institution. The participants' profiles are provided in Table 1.

Table 1. Participant Characteristics

\begin{tabular}{|c|c|c|c|c|}
\hline Participant & Title & Discipline & $\begin{array}{c}\text { Years } \\
\text { Teaching } \\
\text { in Higher } \\
\text { Education }\end{array}$ & $\begin{array}{c}\text { Years Teaching } \\
\text { with Service- } \\
\text { Learning }\end{array}$ \\
\hline Matt & Associate Professor & $\begin{array}{c}\text { Sociology \& } \\
\text { Anthropology }\end{array}$ & 12 & 7 \\
\hline Jennifer & Faculty/Administrator & $\begin{array}{c}\text { English \& } \\
\text { Women's and } \\
\text { Gender Studies }\end{array}$ & 11 & 4 \\
\hline Jessica & Associate/Administrator & $\begin{array}{c}\text { Strategic } \\
\text { Communications }\end{array}$ & 22 & 20 \\
\hline Steve & Associate Professor & English & 15 & 14 \\
\hline Janice & Associate Professor & $\begin{array}{c}\text { Nutritional } \\
\text { Sciences } \\
\end{array}$ & 15 & 13 \\
\hline Julia & Associate/Administrator & $\begin{array}{c}\text { Strategic } \\
\text { Communications }\end{array}$ & 13 & 13 \\
\hline Monica & Professor & Education & 27 & 27 \\
\hline
\end{tabular}

\section{Findings}

\section{Influences for Faculty Use of the Service-Learning Pedagogy}

The first research question explored what influences university faculty to utilize the servicelearning pedagogy in their scholarship of teaching and learning. The two main themes that emerged through the analysis of the data were that: (1) the experiential components of the service-learning pedagogy are effective in connecting students to real-world problems; and (2) service-learning as part of the curriculum engages students in deeper learning.

All of the participants identified service-learning as a viable teaching pedagogy, describing it as a method for learning and reflecting that combines academic classroom curriculum with meaningful service through partnerships in the community. An example of this was provided by Steve who shared that his service-learning courses enable his students and himself "to work with agencies and organizations outside the class while reaching the stated outcomes of the course," which he said motivates him to continue to use service-learning in his courses. Monica also shared that she is motivated to use the pedagogy as it allows her to "continue to find ways of improving the projects and expanding opportunities for students...."

Another influence noted by the participants was that using service-learning enhances their teaching in various ways, one being that it makes them more thoughtful professors. Jessica 
shared that using the service-learning pedagogy makes her "think about teaching in a different way than I had before, because I thought of [the discipline] as only a professional experience for my students and clients." Janice noted that she perceives service learning ensures her "students are going to learn more. It [service-learning] is going to be of greater value. The same information that can come from a classroom and coupled with the service experience is going to enrich the experience for the student."

The participants also provided personal reasons and motivations that have influenced their use of the service-learning pedagogy in their teaching. These included that they are passionate about service-learning, which motivates them to continue to use it within the scholarship of their teaching and learning. They also perceived that it has provided them the opportunity to look at societal issues or problems that are of interest to them, though the lens of service to the community. Julia shared an example of this, stating that "even though we're not getting any money (for incorporating service-learning into our teaching), it's more interesting for me as I can work on things that I find interesting."

The participants mentioned that utilizing the service-learning pedagogy in their scholarship of teaching and learning was also an influence because it benefits their students and the extended community. Jennifer commented that "service-learning helps demonstrate to students how course content relates to real life," adding that "...it disrupts dominant ideas of community service and volunteering as a one-way street and shows students that we, the volunteers, can learn things from them, the people/organizations in need, too."

A majority of the participants perceived that learning can be accomplished in multiple ways through the use of the service-learning pedagogy, sharing that their students not only come away with a better understanding of the course but also learn more about themselves and the community when the service-learning pedagogy is used. Matt and Steve discussed that servicelearning allows them to educate their students about the community as well as themselves, which puts the theories or topics the students learn in the classroom into authentic practice. Janice reflected on how she likes for her "students to get involved in their surroundings, in their environment, and in their community because it is part of her teaching method to help her students to learn from the community."

The participants also mentioned service-learning in connection to experiential learning was an influence to utilize the pedagogy in their teaching. They expressed that service-learning and experiential learning allow students to take the learning in the classroom and apply it outside to the community, which they all perceived was an important component of student learning. All of the participants identified service-learning provides the students the opportunity to learn from real life or hands-on experiences by providing those opportunities to work with the extended community. Julia talked about how the learning outside the walls of higher education allows more realistic and powerful experiences for the students:

I use client work, where I always have a project, because our program is so professionally based, that we want students to get that experience that replicates what it is like outside of the academy... We think that client projects can create a more robust learning experience, a more realistic learning experience. I think students enjoy working with outside partners.

Jennifer went further by discussing the importance of experiential learning to higher education and society: 
Students spend all of this money, and then they get into the workforce, and they're not prepared. They don't know how to be an actual person in a company, in a corporation, and so the call for experiential learning is quite great at this point in time, and we often think about that in terms of internships or [practicum]. Well, internships are probably at the top of the list, but service-learning puts the students in the community in many of the same ways and meets that need that we're receiving a little bit of heat for at the moment.

An additional influence identified was that the integration of service learning into the curriculum strengthens the learning that occurs. The participants described that they integrate service-learning into their curriculum to help their students understand the role of service, to help their students gain more than just professional experiences and skills, and to enhance or change their own teaching style. Janice addressed that she integrates service learning into the curriculum because she teaches "a pre-professional group that needs to be, and their whole emphasis, or one of their primary emphasis, is service. They're a healthcare profession group, and we deal in service." She went on to say that "it just made sense to me to incorporate their supervised practice or practicum experiences in the community, coupling it with a service to a particular organization that we work with."

Some of the participants identified the need to add something more to the curriculum to enhance their students' professional skills. Janice described how teaching with servicelearning has enriched her courses as they have "...certainly gotten richer. Since I have been more formally educated about service-learning and what it means, certainly my courses have been enriched by providing more of the classroom component or the lecture component along with the service."

The final influence that was identified was that service-learning forces faculty to highly engage in their courses and the curriculum. Julia described how her teaching style has changed over the years for the better due to using service-learning:

My teaching style, first of all, has really changed and evolved, I think. I think that's one thing, the longer you teach, I think the better you become... and I think your style adapts. I think I'm much more of an engaging professor today. I feel like I provide content, but I'm also more interested in what the students, how they respond to that content and we come to that... I have in my mind what I want them to achieve, but I let them do more hands-on work, higher level problem solving.

Steve also spoke about how using the service-learning pedagogy has changed his scholarship, teaching style, and curriculum throughout his academic years. He shared how he uses service-learning to meet the learning outcomes for his course:

So, if there is service-learning embedded, it's giving service or connected to one of the outcomes. ...I am able to actually think about the outcome. Any time I teach a course that has a particular outcome, it kind of keys me to think, "Well, one of the best ways to reach that outcome is to have them actually enacting in some way in the community." 


\section{Effects of Service-Learning Pedagogy on Scholarship and Teaching}

The second research question explored how university faculty perceived that utilizing the service-learning pedagogy in their teaching affects students learning. The two main themes that emerged from the analysis of the data collected to address this research question were that: (1) the service-learning pedagogy changes students' perspectives; and (2) the service-learning pedagogy leads to community consciousness.

The participants have experienced the effects of the pedagogy in their teaching more so than in their research. All of the participants discussed that having the service component in their courses has enhanced the learning of the course material aspect for the students. Matt shared that "I think the main reason teachers use service-learning is because it helps students learn the course material better." Janice added that the service learning pedagogy enhances student learning and went on to describe the role of the faculty member:

For the faculty member, it [service-learning] requires a little bit more time maybe than, hanging out in a lab somewhere; certainly requires more skills in dealing with people and interacting. I think a lot of it has to do with the framework of the faculty member, as far as what they think their students are going to gain the most in their learning. I mean, I think about what some of my colleagues do; and the reason they do it is because they think the students are going to learn more; it's going be of greater value. The same information that can come from a classroom, and if that experience is out there; coupled with that... it is going to enrich the experience for the student.

Some of the participants spoke about the difference in dynamics between their servicelearning and non-service-learning classes. Jennifer provided a comparison of the two classes based on the reactions from her students:

Service-learning just changes the classroom dynamic so rapidly. Even before students begin the service-learning project, they know it's coming...And because they will have this moment; because they know this moment where they'll have to perform to put the work into action, when they know it's coming, they are far more attentive.

Monica also discussed changes in dynamics within the classroom of her service-learning courses, sharing that "I intend to provide students with an experience in which they can become sensitive of the significance of developing awareness of culturally relevant teaching practices."

Most of the participants have their students in their service-learning courses do the service component at community partner sites. Matt shared that he perceived "it is really trying to get the students to think about their positionality before they work in the community; and think about the differences between charity, volunteerism, and working with people." He went on to say that he perceives that "It's important that students learn how to work in partnership with community members. It helps them feel more a part of the [university] community and our neighboring communities." $\mathrm{He}$ also noted that his long-term goal is to encourage students "to invest in whatever communities they find themselves in."

The participants also shared that not only does service-learning provide students with the opportunity to be engaged with the extended community, but also to see themselves as individuals who can hopefully make a change. Jennifer shared her thoughts about engagement 
in the community, "...making a difference, it's one of those things you can tell people [the students] that all day, but until they're [students are] actually working with people in the community; ...that's really one of the only things that sells it [service-learning]." Matt added that he sees service learning as a chance for him to give back to the communities within which his university is located.

In addition to making a change, the participants expressed that it is more than being engaged in the community. They mentioned the engagement is also about addressing a social issue or need in the community. An example was provided by Janice, in which she described her course and the service-learning project. She stated that "the purpose of the [project] is to provide a teaching and learning environment for local communities and agencies targeting vulnerable populations with greater economic and/or social needs."

Steve and Monica expressed that students should be engaged in the community in order to learn more about it and its needs and social issues - it raises their community consciousness. Steve stated that:

The whole idea of student engagement is important to me. Thinking about ways in which the community can interact with the coursework, but also ways in which our students can actually contribute to community needs and whatever local and timely issues that are going on are usually important enough to bring into the classroom; so using community as a way to bring issues into the classroom also works out.

Social responsibility and making a change were the perspectives shared among the participants in regard to engaging students in the community. They also discussed that being engaged in the community helps the students learn about social responsibility. As an example, Julia shared that "students are encouraged to envision ways to create mutually beneficial partnerships between corporations and community partnerships in the [university's] social responsibility and public relations course."

Matt expressed that service-learning projects "empower students, showing them that they can make a difference. They give both the students and me a chance to put the [university's] mission statement into practice to help our local community." Julia shared that she had "underestimated [university] students' passion for finding creative solutions to improving community problems."

\section{Summary of the Findings}

A summary of the main findings of this study are presented in Table 2 . There were two main themes that emerged through the analysis of the data to answer both research questions.

\section{Table 2. Summary of Main Findings}

\begin{tabular}{|c|l|}
\hline \multicolumn{1}{|c|}{ Research Questions } & \multicolumn{1}{c|}{ Main Findings } \\
\hline $\begin{array}{l}\text { 1. What influences university faculty } \\
\text { to utilize the service-learning }\end{array}$ & $\begin{array}{l}\text { The experiential components of the } \\
\text { service-learning pedagogy are } \\
\text { effective in connecting students to } \\
\text { real-world problems. }\end{array}$ \\
\hline
\end{tabular}

Journal of the Scholarship of Teaching and Learning, Vol. 18, No. 4, December 2018.

josotl.indiana.edu 


\begin{tabular}{|l|l|}
\hline $\begin{array}{l}\text { pedagogy in their scholarship of } \\
\text { teaching and learning? }\end{array}$ & $\begin{array}{l}\text { Service-learning as part of the } \\
\text { curriculum engages students in } \\
\text { deeper learning. }\end{array}$ \\
\hline \begin{tabular}{l} 
2. $\begin{array}{l}\text { How do university faculty } \\
\text { perceive that utilizing the service- } \\
\text { learning pedagogy affects student } \\
\text { learning? }\end{array}$ \\
\cline { 2 - 2 }
\end{tabular} & $\begin{array}{l}\text { The service-learning pedagogy } \\
\text { changes students' perspectives. }\end{array}$ \\
$\begin{array}{l}\text { The service-learning pedagogy leads } \\
\text { to community consciousness. }\end{array}$ \\
\hline
\end{tabular}

\section{Discussion of the Findings}

Faculty in research universities continue to look for ways to enhance their teaching, research, and professional service (Bowen, 2010), and one way they can do this is through the utilization of the service-learning pedagogy. Ward (2003) perceives that providing faculty views and perceptions about the use of the service-learning pedagogy may reveal the importance of it as a form of scholarship and its effects on the scholarship of teaching and learning.

The perceptions of the participants in the current study are that service learning is a valid pedagogy influences their use of it in their teaching, which is supported by Langseth and Plater (2004) and Strait and Lima (2009), who stated that service learning in higher education would not exist without faculty acceptance of it as a valid educational pedagogy. Service-learning influences the way faculty teach (Ward, 2003). This was evident in the findings of this study as the participants unveiled that service learning enhances their teaching style by allowing them to become more knowledgeable and creative through the use of the pedagogy. In addition, the pedagogy allows them to be innovative and creative in how they integrate the academic content and the service component to enhance their teaching and learning. These findings are supported by Boyer (1996) who noted that faculty member's knowledge, integrity, persistence, and even creativity are important factors that may influence or impact their scholarship within teaching and learning.

The findings of this study indicate that participants are influenced to use the servicelearning pedagogy as it enables them to enhance student learning, connect content to the service experience, as well as to enhance their own teaching for the betterment of their students. The importance of these findings is supported by the work of Li et al. (2007) who found that the college students expect a more stimulating educational experience to maintain interest, concentration level, and motivation, which service learning can provide as it is an innovative teaching method that stimulates the educational experiences of students (Colby, Ehrlich, Beaumont, \& Stephens, 2003).

A majority of the participants affiliated service-learning with experiential learning, since the learning occurs outside the classroom, allowing students to apply their new knowledge to real world experiences. It is through the community partnerships that students are able to enhance their academic knowledge (Cress et al., 2005; Zlotkowski, 1998). Participants in this study acknowledged that they perceive that the learning that occurs outside the classroom allows for a more realistic educational experience, which was also identified as an influencer for faculty to utilize service-learning in their teaching.

Langseth and Plater (2004) state that "service-learning can be central to achieving greater academic depth by extending the relevance of subject matter beyond the classroom and expectations of performance within it" (p. 74). By being a part of the curriculum, service- 
learning provides the opportunity for students to use their skills and learning in actual situations (Cress et al., 2005). Stelljes (2008) adds that philosophically, service-learning supports that education and social responsibility must be connected, leading to the most effective learning as it is active and connected to the experience in some way.

As Eyler and Giles (1999) identified, the service-learning objectives must relate to the course outcomes to enhance students' learning. This point was also supported by the participants in this study. According to Jacoby and Associates (1996), the design of servicelearning curriculum enables students to fulfill the goals of the learning objectives of the course, while also meeting the needs of the community partner. Ehrlich (2000) states that teaching with the service-learning pedagogy means paying as much, if not more, attention to how we teach and how students learn than to what we, as educators, teach and learn. The integration of the service experience into the curriculum can advance the academic agenda (Eyler \& Giles, 1999). Stelljes (2008) identifies that the service experience combined with learning adds value to the service and students' learning and transform both. It is when the service and learning are integrated that it transforms the educational experience for the students.

As higher education institutions are facing pressures from the community for students to obtain better applicable workplace skills, colleges and universities are searching for strategies to provide quality learning experiences for their students (Bowdon et al., 2008). Connors et al. (2000) support that community organizations and community partners play significant roles in how college students are educated, and the service-learning pedagogy can be used to support this education and collaboration. The findings of this study support Connors et al.'s work as all of the participants perceived that the service learning pedagogy is an effective quality teaching tool and is a strategy that supports quality learning experiences (Strait \& Lima, 2009). The majority of the participants perceived that the service-learning pedagogy benefits the students, the extended community, and their own scholarship of teaching and learning as the academic curriculum is aligned with community partners' needs.

O'Meara (2008) identified that there are both personal and professional factors, and motivators that influence faculty to utilize the service-learning pedagogy in their teaching. Examples of this were provided by some of the participants in this study who discussed that they are invested and passionate about the pedagogy. It is through faculty passion and persistence in the integration of service-learning into courses that have helped raise service learning's visibility in higher education (Strait \& Lima, 2009). According to Birge (2005) and Schwendener-Holt (2005), faculty members may participate in service-learning because of their personal commitment to the pedagogy, further supporting how personal emotions may have an influence in faculty motivation to integrate service learning into their curriculum.

Jacoby and Mutascio (2010) note that faculty may utilize their service-learning experiences in their research and scholarship by connecting the pedagogy to their roles as scholars. A majority of the participants in this study discussed they utilize the service-learning pedagogy as a method to relate their curriculum and service to assist in their teaching. The findings in this study did not fully support the existing literature that faculty utilize the servicelearning pedagogy in their scholarship of teaching and learning, mainly due to a lack of support for this by the participants' department and institution. Though researchers such as Boyer (1990) caution that higher education should develop scholarship connected to and integrated with service, this does not appear to be prevalent in the study institution.

Journal of the Scholarship of Teaching and Learning, Vol. 18, No. 4, December 2018. josotl.indiana.edu 


\section{Effects of Service-Learning Pedagogy on Scholarship and Teaching}

The participants embrace the service-learning pedagogy because it enhances student learning. Service-learning has the ability to enhance learning of the academic content through engagement with the extended community, as well as provides experiences with real-life connections between the students' education and community issues (Redlawsk et al., 2009). A majority of the participants in this study indicated that no matter the discipline, service-learning does have an effect on their courses and as well as their students' learning of the course materials. As identified by Eyler and Giles (1999), service-learning plays a vital role in assisting students to learn through the service experience. Educational experiences of students should motivate them to take action to enhance their academic knowledge. Dewey (1938) posited that education must be based on experiences in which things are not known and learned, unless the knowledge comes from observation and actions. Service-learning provides faculty an alternative method to enhance learning for their students. As noted by Cress et al. (2005), service-learning provides students a different way to learn.

Service-learning educators should be reflective as well as reflexive in meeting the needs of society through purpose, practice, and partnership (Strait \& Lima, 2009). All of the participants in this study found a way to integrate the service experience into their courses, perceiving that this has advanced their academic agenda in one way or another. The participants also indicated that they wanted their students to see that there is a purpose in what they learn.

Some of the participants mentioned the main influence that has made service-learning effective in their teaching was the goal to utilize the pedagogy as a means to enhance their students' learning. Service-learning provides opportunities for faculty to experience a different teaching methodology. This finding is supported by Langseth and Plater (2004) who discussed that educators need to introduce and foster skills in the classroom within the context of activating the imagination through exploration and discovery. It is through service-learning that faculty can inform their teaching practice (Cooper 2013) to enhance student learning. The work of Seifer and Connors (2007) also supports this finding. They found that an effective outcome of service-learning is the ability to balance the service that is provided with the learning that takes place. Dewey (1938) addressed that students cannot understand their roles in society unless they continuously reflect on what they do throughout the process.

An additional finding in this study was that some of the participants use service-learning to engage their students in the community to expose them to social issues. This use of service learning is supported by the work of Bringle et al. (2004) and Langseth and Plater (2004) who identified that service-learning provides students the opportunity to learn about the social issues or needs in the local community. Zlotkowski (1998) maintains that students not only learn about social issues in service-learning, but they are able to address real problems in their community through this experience. The usage of service-learning encourages students to consider unique solutions to authentic problems through application of course content (Bringle et al., 2004).

All of the participants in this study acknowledged that it is within the service experience that students get to learn from the community as it provides the students an opportunity to put into practice what they are learning in the classroom (Bowen, 2010) to respond to communityidentified concerns (Seifer \& Connors, 2007). Engaging students in the community, as the literature has shown (e.g., Bok, 2006; Jacoby \& Associates, 1996), may provide opportunities for students to learn more about their personal skills as well as civic and social responsibilities. As noted by Bok (2006), service-learning allows individuals to focus on critical and reflective 
thinking as well as personal and civic responsibility. Today's college graduates need to be positive contributors in society and they must be able to understand the importance of their role in this (Colby et al., 2003). Service-learning engages students in authentic situations in the real world, which helps them to build their understanding of their role in the community (Eyler \& Giles, 1999). Based on the findings of this study, the participants perceived that student engagement with the community provide faculty with a purpose, which according to Ward (2003), can be a powerful intrinsic motivator to continue to utilize this pedagogy to advance student learning.

Colleges and universities have a long tradition of fulfilling their responsibilities to the extended community and to society as a whole (McIlrath, Lyons, \& Munck, 2012). Students have the opportunity to learn about social and civic responsibilities through engagement with the community through service-learning. Some of the participants discussed that they facilitate students' development of social responsibility by including the campus community within their service-learning courses. This finding is supported by the literature, which states that the first step in rebuilding civic life outside of the academy is to rebuild civic life within the academy (e.g., Ehrlich, 2000). The faculty participants also discussed the importance of engaging students in the community in order to provide them opportunities to develop not only their professional skills but also their civic skills. As the definition for service learning implies, service-learning enhances a sense of civic responsibility (Bringle \& Hatcher, 1995). According to Bok (2006), if students practice social and civic responsibility skills within their own campus community, these behaviors are assumed to carry over into their life experiences outside of college.

\section{Implications for Higher Education}

The findings of the study suggest several implications for service-learning in higher education. As Butin (2010) mentions, it is "service-learning's ability to function and spread across the panoply of higher education" that is "part of what makes it such an appealing pedagogical and philosophical model" (p. 144). The underlying idea behind the purpose of teaching and learning is that the power of the personal experience will compel students to learn more profoundly and be able to apply knowledge more broadly (Birge, 2005). Service-learning challenges the traditional practices in higher education of focusing on teaching, learning, and research, by supporting practices that are deeply engaging, local, and impactful (Butin, 2010).

The first implication of the findings of this study is that higher education institutions need to find ways to support faculty members in engaged scholarship, service-learning research, and the scholarship of teaching and learning, or it will not occur at the institution. Butin (2010) states that it is the linkage of academic practice with community engagement that is of importance in higher education, arguing that the vision and practice of service-learning is as urgent today as it was decades ago. Yet, institutional practices and policies still appear to favor research in the faculty's discipline than within their teaching and learning within the servicelearning pedagogy.

Administrative leadership has a role in making fundamental changes to service-learning as an academic initiative, which has the potential to enhance their faculty's scholarship and research endeavors. As Butin (2010) mentioned, "the changing face of student demographics, faculty profiles, and institutional structures and practices necessitates a fundamental rethinking of how" engaged scholarship should thrive in higher education (p. 152). If colleges and 
universities do not make changes to their institutional policies and procedures to include service-learning, higher education institutions prevent their faculty from contributing to the literature of the scholarship of teaching and learning and engaged research.

Another implication for higher education is that it needs to move engagement, including service learning from the margin to the mainstream of its research, teaching, and service work (Fitzgerald et al., 2012). Higher education institutions should continue to explore ways to support their faculty in their service-learning endeavors. Without support, faculty may not pursue engaged research endeavors. Administrative support has been shown in the literature to be an important motivator for service-learning faculty. As stated by Welch and Billig (2004), it is through institutional support that administrators will recognize the research efforts of their service-learning faculty as engaged scholars within the scholarship of teaching and learning.

The final implication for higher education institutions is that failure for institutions to view their faculty's work with the service learning pedagogy as "scholarly work that can and should contribute to the body of knowledge within their own fields while simultaneously contributing to community improvement and students' civic engagement" (Welch \& Billig, 2004, p. 231), will lead to faculty dissatisfaction and a failure by the institutions to demonstrate their engagement in the community. Boyer (1990) envisioned broader scholarship within the context of the academy, which includes the scholarship of engagement or engaged research.

\section{Conclusion}

Part of the mission of higher education is to provide educated and responsible citizens, which has been discussed in the literature (e.g., Bok, 2006; Butin, 2010; Jacoby \& Associates, 1996). It is Dewey's (1910) philosophy that there is a need for individuals to become thoughtful and educated citizens (Butin, 2010). It is through service-learning research and engaged research that responsible and educated citizens can be developed.

The service-learning pedagogy can provide opportunities for integrating issues related to professional responsibility, social justice, diversity and stereotypes, and public policy to name a few. Through participation in service learning, students will become more aware of the issues in the community and develop a sense of responsibility for addressing those issues (Zlotkowski, 1998). Certainly, many aspects of the college experience will force students to assume new roles and exhibit new knowledge, behaviors, and characteristics of responsible citizenship. These experiences should be considered as scholarly opportunities for faculty to conduct engaged research. As Jacoby and Mustascio (2010) have stated, faculty can utilize the service-learning experiences in their research by connecting it to their roles as scholars. This point is supported by the conceptual framework of this study that was comprised of Boyer's $(1990,1996)$ work that suggests that faculty's knowledge, integrity, persistence, and creativity are important factors in influencing their view and thoughts on scholarship. It is through the use of the service learning pedagogy that opportunities for experiential learning are provided to students, which may influence faculty to conduct pedagogical or engaged research, supporting that service-learning can have a role in the scholarship of teaching and learning in faculty academic careers. 


\section{References}

Astin, A. W. \& Sax, L. J. (1998). How undergraduates are affected by service participation. The Journal of College Student Development, 39 (3), 251-263.

Billig, S. H., Root, S., \& Jesse, D. (Eds.), (2005). The relationship between the quality indicators of service-learning and student outcomes: Testing professional wisdom. Improving service learning practice: Research on models to enhance impact (pp. 97115). Greenwich, CT: Information Age Publishing.

Birge, J. (2005). The aesthetical basis for service-learning practice. In Butin, D. (Ed). Service Learning in Higher Education. New York: Palgrave MacMillan.

Bok, D. (2006). Our underachieving colleges: A candid look at how much students learn and why they should be learning more. New Jersey: Princeton University Press.

Boyer, E. L. (1990). Scholarship reconsidered: Priorities of the professoriate. Princeton, NJ: Carnegie Foundation of the Advancement of Teaching.

Boyer, E. L. (1996). The scholarship of engagement. Journal of Public Service and Outreach, 1(1), 11-20.

Bowdon, M. A., Billig, S. H., \& Holland, B. A. (2008). Scholarship for sustainingservice learning and civic engagement. A volume in advances in service-learning research. Charlotte, NC: Information Age Publishing, Inc.

Bowen, G. (2010). Service learning in the scholarship of teaching and learning: Effective practices. International Journal for the Scholarship of Teaching and Learning, 4(2), 115.

Bringle, R. G., \& Hatcher, J. A. (1995). A service learning curriculum for faculty. Michigan Journal of Community Service Learning. 2, 112-122.

Bringle, R. G., Hatcher, J. A., \& Clayton, P. H. (Eds.). (2006). Research on service learning: Conceptual Frameworks and Assessment. Sterling, VA: Stylus.

Bringle, R. G., Hatcher, J. A., \& Games, R. (1997). Engaging and supporting faculty in service learning. Journal of Public Service and Outreach. 2(1), 43-51.

Bringle, R. G., Phillips, M. A., \& Hudson, M. (2004). The Measure of service learning: Research scales to assess student experiences. Washington, DC: American Psychological Association.

Butin, D. W. (2010). Service-Learning in theory and practice: The future of community engagement in higher education. New York, NY: Palgrave MacMillan.

Casey, K. M., Davidson, G., Billig, S. H., \& Springer, N. C. (Eds.). (2006). Advancing knowledge in service-learning: Research to transform the field. A volume in advances in service-learning research. Greenwich, CT: Information Age Publishing.

Clayton, P. H., Bringle, R. G., \& Hatcher, J. A. (Eds.). (2013). Research on service learning: Conceptual frameworks and assessment, Volume 2A: Students and faculty. Sterling, VA: Stylus.

Colby, A., Ehrlich, T., Beaumont, E., \& Stephens, J. (2003). Educating citizens: Preparing America's undergraduates for lives of moral and civic responsibility. San Francisco, CA: Jossey-Bass.

Connors, K., Kirk, H., J., \& Seifer, S.D. (2000). Improving the preparation of nursing professionals through community-campus partnerships. In Gott, M. (Ed). Nursing Practice, Policy and Change, Radcliffe Medical Press, 11-24.

Journal of the Scholarship of Teaching and Learning, Vol. 18, No. 4, December 2018.

josotl.indiana.edu 
Cooper, L. (2013). Student reflections on an LIS internship from a service learning perspective supporting multiple learning theories. Journal of Education for Library and Information Science, 54(4), 286-298.

Cress, C. M., Collier, P. J., Reitenauer, V. L. \& Associates. (2005). Learning through serving: A student guidebook for service-learning across the disciplines. Sterling, VA: Stylus.

Cruz, L., Ellern, G. D., Ford, G., Moss, H., \& White, B. (2013). Navigating the boundaries of the scholarship of engagement at a regional comprehensive university. Journal of Higher Education Outreach and Engagement, 17(1), 3-26.

Dewey, J. (1933). How we think: A reinstatement of the relation of reflective thinking to the educative process. Lexington, MA: D.C. Heath and Company.

Dewey, J. (1938). Experience and education. New York, NY: Collier.

Erlandson, D. A., Harris, E. L., Skipper, B. L., \& Allen, S. D. (1993). Doing naturalistic inquiry: A guide to methods. Newbury Park, CA: Sage.

Ehrlich, T. (2000). Civic responsibility and higher education. Phoenix, AZ: Oryx Press.

Eyler, J., \& Giles, D. E. (1999). Where is the learning in service-learning? San Francisco, CA: Jossey-Bass.

Fitzgerald, H. E., Burns, K., Sonka, S. T., Furco, A., \& Swanson, L. (2012). The Centrality of engagement in higher education. Journal of Higher Education Outreach and Engagement. 16(3), 7-27.

Glassick, C. E. (2000). Boyer's expanded definitions of scholarship, the standards for assessing scholarship, and the elusiveness of the scholarship of teaching. Academic Medicine, 75(9), 877-880.

Jacoby, B. (2003). Building partnerships for service-learning. San Francisco, CA: JosseyBass.

Jacoby, B., \& Associates. (1996). Service-Learning in higher education: Concepts and practices. San Francisco, CA: Jossey-Bass.

Jacoby, B., \& Mutascio, P. (2010). Looking in reaching out: A reflective guide for community service-learning professionals. Boston, MA: Campus Compact.

Keshen, J., Holland, B. A., \& Moely, B. E. (2010). Research for what? Making engaged scholarship matter. A Volume in Advances in Service-learning Research. Charlotte, NC: Information Age Publishing, Inc.

Langseth, M., \& Plater, W. M. (2004). Public work \& the academy: An academic administrator's guide to civic engagement and service-learning. Bolton, MA: Anker Publishing Company, Inc.

Li, T., Greenberg, B. A., \& Nicholls, J. A. (2007). Teaching experiential learning: Adoption of an innovative course in a MBA marketing curriculum. Journal of Marketing Education. (29) 25-33.

Lincoln, Y. S., \& Guba, E. G. (1985). Naturalistic inquiry. Beverly Hills, CA: Sage.

McIlrath, L., Lyons, A., \& Munck, R. (2012). Higher education and civic engagement comparative perspectives. New York, NY: Palgrave Macmillan.

McKinney, K. (2006). Attitudinal and structural factors contributing to challenges in the work of the scholarship of teaching and learning. In J.M. Braxton (Ed.), Analyzing Faculty Work and Rewards: Using Boyer's Four Domains of Scholarship, New Directions in Institutional Research. San Francisco: Jossey Bass.

Merriam, S. B. (2009). Qualitative research: A guide to design and implementation. San Francisco, CA: Jossey-Bass. 
Mezirow, J. (2000). Learning to think like an adult: Core concepts of transformative learning. In J. Mezirow \& Associates, Learning as transformations: Critical perspectives on a theory in progress (pp. 3-34). San Francisco, CA: Jossey Bass.

O'Meara, K. (2008). Motivations for faculty community engagement: Learning from exemplars. Journal of Higher Education Outreach \& Engagement. 12(1), 7-30.

Redlawsk, D. P., Rice, T. \& Associates. (2009). Civic service: Service-Learning with state and local government. San Francisco, CA: Jossey-Bass.

Schwendener-Holt, M. (2005). Peaks and valleys: Lessons from the service-learning mountain. In M. Bellner \& J. Pomery, Service Learning: Intercommunity and Interdisciplinary Explorations (pp. 63-72). Indianapolis: University of Indianapolis Press.

Seifer, S. D., \& Connors, K. (Eds.). (2007). Faculty toolkit for service-learning in higher education. Scotts Valley, CA: National Service-Learning Clearinghouse.

Shulman, L. S. (2004). Teaching as community property: Essays on higher education. San Francisco, CA: Jossey-Bass.

Stelljes, A. (2008). Service-Learning and community engagement. Amherst, NY: Cambria Press.

Strait, J. R., \& Lima, M. (Eds). (2009). The Future of service-learning: New solutions for sustaining and improving practice. Sterling, VA: Stylus Publishing, LLC.

Vogel, A. L., Seifer, S. D., \& Gelmon, S. B. (2010). What influences the long-term sustainability of service-learning? Lessons from Early Adopters. Michigan Journal of Community Service Learning. Fall, 59-76.

Ward, K. (2003). Faculty service roles and the scholarship of engagement. ASHE-Eric Higher Education Report, 29(5), 1-125.

Welch, M. \& Billig, S. H. (2004). New perspectives in service-learning research to advance the field. A volume in advances in service-learning research. Charlotte, NC: Information Age Publishing, Inc.

Westover, J. H. (Ed.). (2012). Academic service-learning across disciplines: Models, outcomes, and assessment. Champaign, IL: Common Ground Publishing.

Wilczenski, F. L., \& Coomey, S. M. (2007). A practical guide to service learning: Strategies for positive development in schools. New York, NY: Springer Science +Business Media, LLC.

Zlotkowski, E. (Ed.). (1998). Successful service-learning programs: New models of excellence in higher education. Boston, MA: Anker Publishing Company, Inc. 